\title{
The Prospects for Diversification of Slovak Export to
}

\section{Asia}

\author{
Radomír Boháč \\ University of Economics in Bratislava, Faculty of International Relations, \\ Department of International Economic Relations \& Economic Diplomacy, \\ Bratislava, Slovak Republic
}

\begin{abstract}
The centre of gravity of international trade has been shifting eastwards; 2 of 3 largest economies come from Asia. It witnessed $6.9 \%$ growth in 2014, much above the $2.6 \%$ on the global level. Credit goes in full to continent's hard working population. It is presumed that $90 \%$ of the global growth within the next $10-15$ years will be generated outside Europe; the majority of it in Asia. By 2050 a half of the global GDP will be generated there. Asia represents the global model in promoting R\&D and innovations; it has become the key trading partner of the EU, with strategic partners in China, India, Japan, and South Korea. Numerous EU's FTAs are being negotiated, hopefully eliminating remaining barriers to trade. The contribution focuses on prospects which are emanating for Slovakia and the Western liberal economic model vis-a-vis state control. It discusses the China's economic downturn as a risk but also as a new opportunity. Slovak prosperity is vitally interlinked with the performance of export. It disproportionately depends on the EU. Out of the first eight countries within Slovakia's negative trade balance statistics, six come from Asia. Thus Asia should imperatively facilitate diversification of Slovak economy. The paper attempts to establish a frank and open picture of the state of the game, with the right balance between theory and authentic professional experience of the author. It assesses key Slovak strengths and weaknesses, identifies opportunities and offers a "food for thought".
\end{abstract}

Keywords: Slovakia, Export, Asia, International Trade

\section{INTRODUCTION}

The economy of Slovakia is the most open among the V4 countries and after Luxembourg (event. also Ireland) the second (or third, respectively) most open within the European Union. From this perspective, it remains ahead of numerous other smaller economies of the Eurozone, such as Malta, Cyprus, Latvia, Estonia or Slovenia (Morvay, 2015). In 2014 the Slovak foreign trade increased by $1 \%$ to $€ 64.8$ billion. The openness of the economy, as the proportion of foreign trade with commodities related to the Gross Domestic Product (GDP) of the country (in 2014 the GDP increased by 3.5\%) stands at $167 \%$ (compared to $172 \%$ in 2013 ).

The discourse about the need for Slovak export diversification has existed not least since the beginning of the global financial crisis in 2008. The incentives for a more significant profiling of the Slovak economy abroad have repeatedly been embedded in national strategic economic documents. A plethora of measures designed to diversify export has been adopted, even though their effectiveness is, to say the least, limited: the share of Slovak export to the EU oscillates in the long term around the "magical" figure of $85 \%$. In 2014 export to other EU countries reached $84.1 \%$ share again - with the full knowledge of discrepancies in domestic and foreign statistics (cars - the dominant export commodity - are in many cases re-exported to markets outside the continent via European carmakers' headquarters).

What are the causes? What other measures must the state adopt in its economic policies to mitigate the vulnerability to even the smallest fluctuations in the European economic area? Would the 


\section{Radomír Boháč \\ The Prospects for Diversification of Slovak Export to Asia}

continued weakening of the Euro help to increase activities of the private sector in non-Eurozone and, particularly, non-EU markets? Or will it more likely weaken the trade balance through more expensive import, since the Slovak passive trade balance is dominated by partners outside the EU (with Asia representing the first seven: South Korea - $€ 4.27$ bil., China - $€ 3.27$ bil., Vietnam - $€ 1.77$ bil., Japan - €661.4 mil., Malaysia - €449.2 mil., Taiwan - €426.2 mil. and India - €202,2 mil.). The prospects for a higher trade dynamics are not supported by economic forecasts for 2016: economic growth exceeding $2 \%$ is not expected in the Eurozone or Germany - Slovakia's key trade partner. The „EU 27 " share on the added value until 2003 constituted 29\%, whereas in 2011 it was just 24\% (Svocáková, 2014).

\section{Asia: What it offers Now, Perspectives, Megatrends}

The centre of the world trade is irreversibly shifting towards the East, despite the abundance of challenges, which the continent has faced throughout the last three decades. In the aftermath of the Second World War the majority of Asian states struggled with extreme poverty, they were recovering from the fallouts of the war with the need to rebuild infrastructure while having to confront their colonial past (most often it was the combination of all three factors). Since then the situation has dramatically changed: two of the three largest economies come from Asia (China in second and thirdplaced Japan). China (the highest growth forecasted in steel, household goods, finance sector and construction) should overtake the United States as the world's largest economy by 2030; while India should claim the second place (the growth expected particularly in IT, services, pharmaceutics and car industry) in the next decade (the World Bank).

South Asia, as well as East Asia and Pacific, have in 2014 experienced an average economic growth of $6.9 \%$, well above the world's rate of $2.6 \%$ (World Bank's estimate). The credit for this advancement should unhesitatingly be accorded to the notorious Asian work ethics - $20^{\text {th }}$ century witnessed the rapid industrialisation of Japan in the 1950s, followed by Hong Kong, Taiwan, Singapore and South Korea by the 1960s, or China in the 1970s (perhaps only by coincidence during authoritarian regimes). Hong Kong or Singapore based their economic policies on the liberalisation of trade and financial services, while Taiwan, South Korea and, especially, China on manufacturing. Flirting with socialist economic models has in countries such as China, India or Indonesia proved inefficient - China has since had these approaches reformed, while others have relinquished them. The continent comprises the population of 4.5 billion (half of which come from China and India), which constitutes up to $60 \%$ of the world's population.

It is estimated that $90 \%$ of global economic growth in the next 15 years will be generated outside Europe, mostly in Asia. The Asia Development Bank (ADB) estimates that by 2050 Asia will have produced $50 \%$ of the world's GDP (currently - in 2014 - Asia and Pacific's share constitutes $41.7 \%$ IMF World Economic Outlook). By long-term active balance with the West Asia has accumulated more than half of the world's currency reserves - exceeding \$4 billion. Perhaps even more importantly, the Far East plays a leading role in promoting R\&D and innovation.

In the light of the above, it comes as no surprise that Asia has become the EU's key trade partner. The Union has so far concluded four strategic partnerships (with China, India, Japan and South Korea). Trade liberalisation continues and includes negotiations of numerous new free-trade agreements (with Brunei, Fiji, Indonesia, Japan, Malaysia, Vietnam, and, to more limited extent, with India and Thailand) hopefully resulting in the elimination of remaining, particularly non-tariff, trade barriers. Since 2011 the FTA with South Korea already in force covers $70 \%$ of mutual trade; FTA with Singapore has since 2012 encompassed not only trade and services but also the "green" agenda. In 2008 - 2012 the trade between the EU and Asia grew annually on average by 5.8\%. In 2012 the trade with Asia amounted to $21.4 \%$ in the EU exports and $29.8 \%$ of its imports, surpassing the likes of USA and China. The list of EU's top 10 trade partners now contains (2012 data) China (12.5\%), Japan (3.4\%), India (2.2\%) and South Korea (2.2\%) (EEAS). The EU is an equally important investor 
in the East - for instance in 2010 the $17.2 \%$ of the EU's outward investment went to Asia (EEAS). The opportunities are also, undoubtedly, provided by the regional economic integration- ASEAN, SAARC, APEC, and instruments, such as the recently negotiated Transpacific Partnership Agreement (TTP), or dialogues, such as East Asia Summit or Asia-Europe Meeting (ASEM).

The EU member states continue to strengthen their visibility on the continent; they are opening new embassies (with the attention one's. the new Asia "tiger" Vietnam or re-opening Burma/Myanmar), consulates-general and trade offices in the region (mostly in China), while political "obstacles" (e.g. human rights issues) are being overlooked for the benefit of supporting economic/trade activities. This diversification trend with a special and systematic focus on the Asian markets is currently also observed in geographically similar countries in the European Economic Area (EEA), for example, Denmark, the Czech Republic, Switzerland, Sweden, etc.

There is a downside, however, for the rapid economic growth is logically associated with many risks. The Asian continent has for a long time been politically, historically and economically one of the most complicated regions, as George Friedman eloquently observes: „Asia is a place of perpetual changes and many things, which currently appear constant, will within the next ten years go through a deep transformation"(Friedman, 2011). While economic interdependence in Asia is further deepened, there is a growing number of frictions and instability stemming from the absence of mutually agreed "code of conduct" and relevant security infrastructure. From international trade perspective, the critical question remains the need for freedom of navigation. Around $90 \%$ of the world trade depends on the maritime transport, while its precariousness is salient especially in this region with several critical channels and straits, such as the Strait of Malacca; relevant, though to a smaller extent, is also the competition for maritime mineral resources or fishery. The basic equation of this strategic situation is increasingly defined by highly competitive China, which is claiming the role of the US as the region's principal power. The new emerging regional phenomenon is the increasing nationalism and raising of historical grievances in bilateral relations.

Since, as stated above, Asia is one of the main engines of global growth, any slowdown of its economy will significantly affect the shape of the world's economy. Simultaneously, it is evident that the prosperity of the region is - next to the growing domestic expenditure - largely dependent on external environment, considering the export-oriented economies of the majority of the countries in the region.

The interdependence is in itself one of the risk factors - its deficiencies were most evident in the Asian financial crisis of 1997, initially invoked by the currency speculations in Thailand and rapidly spreading to affect others (South Korea, Indonesia, Hong Kong, Malaysia, Singapore - in contrast to Japan and Taiwan, which "navigated" through the crisis relatively unharmed).

Special apprehension is raised by (predictably, according to the author) the slowdown in the Chinese growth multiplied by the fall of the prices of shares and properties (the return to double-digit values from the past appears unlikely). Especially in respect to China, the viability of "western" economic model raises several question marks. The confrontation is apparent in enforcing the acceptance of Yuan/Renminbi as a fully convertible trade currency (Pauhofová, I. -Svocáková, S., 2014) ${ }^{1}$, in the creation of the Asian Infrastructure Investment Bank (vs. Asian Development Bank), countering liberalisation by concluding free trade agreements with the EUor TTP with the US and through initiatives, such as, the New Silk Road - One Road, One Belt, China + CEE16 (16 countries of central and eastern Europe) etc. As a consequence of the global financial crisis the role of state in economy is regaining importance, not only in China, which links its national security, inter alia, with increased state control in accessing the sources of energy. "...China seeks to fulfil through foreign investment not only the strategic goals of securing more effectively the needs of its future generations but by

\footnotetext{
1"In international perceptions one of the most meaningful Chinese strategies is the question of currency policy. China seeks to increase the importance of its currency in international context by reducing the dependence on US Dollar through re-directing the autonomous trade streams. It is expected that Chinese Yuan will become Asia's main currency and soon a fully-convertible global currency"
} 
doing so also consolidates its growing role as one of the global hegemons" (Pauhofová, I. -Svocáková, S., 2014).

The heaping currency reserves hardly diffuse worries of potential manipulation with key global currencies, including the Euro. From the perspective of the local markets, for European exporters - in particular smaller countries lacking exquisite excellence of production (read: non-existence of products of global appeal) - the absence in Asia of stronger middle class with disposable wealth, due to the remarkably unequal distribution of economic growth remains important (on the one hand the biggest proportion of billionaires, on the other the sources of income of average household remain much lower than in the US or Western Europe - average European household has a disposable income of $\$ 220.000$, while Chinese just about $\$ 72.000$ ).

Equally important as one of the risk factors is the continent's susceptibility to natural disasters (seismic activity, tsunami, typhoons, climate change, etc.).

\section{The Current Economic Position of Slovakia in Asia}

Slovakia's export is, in comparison with other comparable countries - as Table no. 2 demonstrates dependent mostly on the EU, despite the fact that it lies on its very Eastern border. Although the share of Asian exports (Table no. 1) corresponds to the values of neighbouring Czech Republic and Hungary, it significantly lacks behind other countries. From the perspective of commodities structure (unequivocally dominant is the export of cars) and the specifics of Asian demand (mostly luxury goods, including cars), with the emphasis on the production of Slovak carmakers, the volatility of our export stems from the production programme of Volkswagen; in other words the higher the share of premium production, the higher export to the East. This fact remains a key attribute of our active trade balance with the majority of Asian states.

Table 1: Trade position of Slovakia in Asia

\begin{tabular}{|l|c|c|c|c|c|c|c|c|}
\hline \multicolumn{1}{|c|}{ Year } & $\mathbf{2 0 0}$ & $\mathbf{2 0 0}$ & $\mathbf{2 0 0 9}$ & $\mathbf{2 0 1}$ & $\mathbf{2 0 1}$ & $\mathbf{2 0 1}$ & $\mathbf{2 0 1}$ & $\mathbf{2 0 1 4}$ \\
\hline $\begin{array}{l}\sum \text { Export (mil. } \\
€ \text { ) }\end{array}$ & 42091.0 & 47720.0 & 39715.6 & 48272.1 & 56783.2 & 62144.0 & 64172.3 & 64800.9 \\
\hline Share the EU & $86.7 \%$ & $85.2 \%$ & $85.7 \%$ & $84.2 \%$ & $84.7 \%$ & $83.7 \%$ & $82.8 \%$ & $84.1 \%$ \\
\hline Share Asia & $3.5 \%$ & $3.9 \%$ & $4.6 \%$ & $5.2 \%$ & $5.4 \%$ & $5.1 \%$ & $5.9 \%$ & $5.2 \%$ \\
\hline
\end{tabular}

Sources: The Statistical Office of the Slovak Republic, Ministry of Economy of the Slovak Republic, Ministry of Foreign and European Affairs of the Slovak Republic 


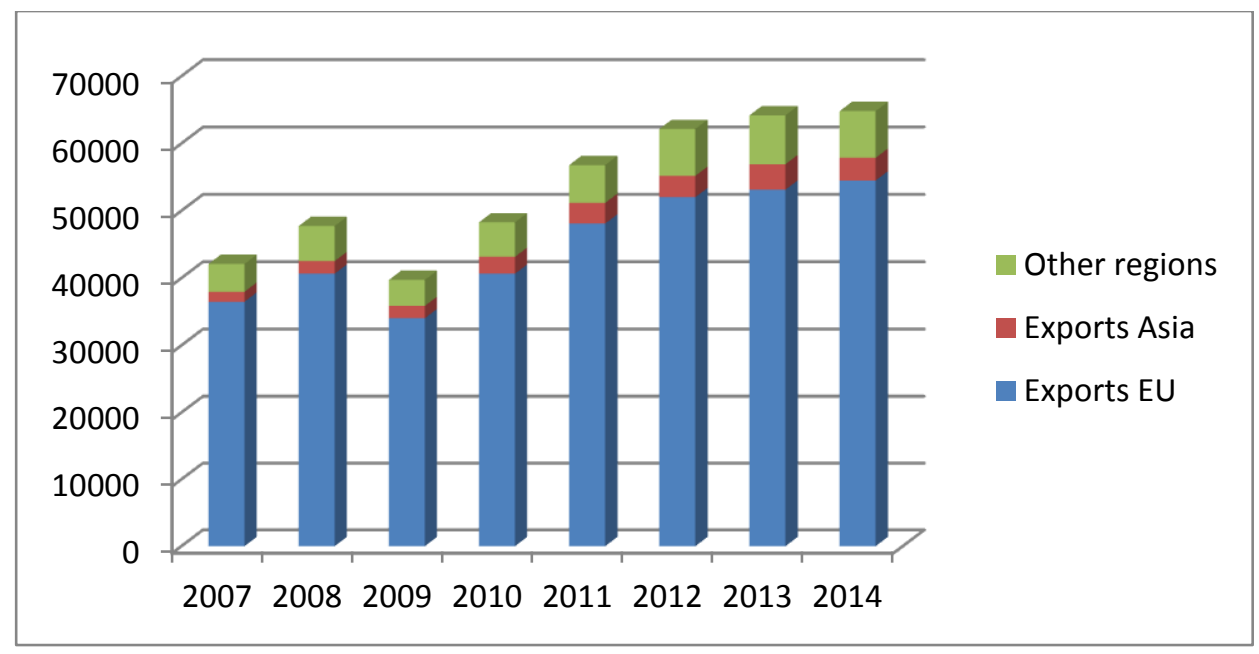

Chart 1: Geographical orientation of Slovak exports 2007 - 2014

Sources: The Statistical Office of the Slovak Republic, Ministry of Economy of the Slovak Republic, Ministry of Foreign and European Affairs of the Slovak Republic

Table 2: Geographical structure of exports - the EU and Asia - in similar countries

\begin{tabular}{|l|l|l|l|l|l|l|l|l|l|l|l|l|}
\hline (in \% points) & AT & BE & CH & CZ & DK & FI & HU & HR & NO & NL & SE & SI \\
\hline EU & 67.2 & 70.1 & 54.8 & 81.0 & 57.4 & 53.4 & 77.0 & 59.1 & 81.7 & 72.8 & 56.1 & 76,3 \\
\hline Asia & 13,0 & 11,0 & 35,5 & 5,2 & $\mathrm{ca} .20$ & 12,0 & 5,3 & n/a & 8,4 & n/a & 12,5 & 4,6 \\
\hline
\end{tabular}

Sources: WTO (September 2014), Statistical Offices of AT, SI, CH, SE (January - July 2015), BE (January - June 2015); Tulli.fi

\subsection{Trade Balance of Slovakia with leading Asian countries}

On the turnover, there is an unequivocal dominance of trade with China. The dynamics of importstrengthening has not experienced any trepidation, not even during the global crisis. In contrast with Japan, containing more technology-dominated import, import from China consists primarily of goods designed for final consumption. The share of cars imports stands at significant $67.3 \%$. With the exception of 2014 export has grown, while the passive balance still amounts to just below $€ 3.3$ billion.

In the world's second most populous country - India, trade with Slovakia has been underperforming; indicating our quasi-departure from the territory - with a turnover of just $€ 264$ million. The share of cars on overall export is here at it's lowest (6.6\%).

South Korea is the leader - given almost $€ 2$ billion of investments (imports mostly inputting local manufacturing processes) - in the ranking of the Slovak negative balance ( $€ 4.2$ billion), even though in the past year we have experienced a slight decrease (import at $84.7 \%$ in comparison with 2013, juxtaposed with $30.3 \%$ increase of export - large disproportion between the import and export gives no reason to celebrate). The dependence on the car industry is at $40 \%$.

Japan is leading in the share of cars - up to $75 \%$. Trade turnover with Slovakia in 2014 reached $€ 871$ million; import exceeding export more than sevenfold. Following the post-crisis growth on both sides of trade, a partial slowdown ensued in 2014.

In respect to Southeast Asia (ASEAN) Vietnam remains our most important trade partner. The Slovak Ministry of Economy omitted its position within the summary of negative trade balances - $€ 1.7$ billion, 
which puts Vietnam at the $4^{\text {th }}$ place $(V y ́ v o j, 2015)^{2}$. This is mostly due to the import of components for Samsung Electronics.

Table 3: Trade between Slovakia and ASEAN (millions of $€$ )

\begin{tabular}{|l|l|l|l|l|l|}
\hline Year & $\mathbf{2 0 1 0}$ & $\mathbf{2 0 1 1}$ & $\mathbf{2 0 1 2}$ & $\mathbf{2 0 1 3}$ & $\mathbf{2 0 1 4}$ \\
\hline Import & 78 & 76 & 104 & 92 & 94 \\
\hline Export & 750 & 859 & 1048 & 1929 & 2639 \\
\hline Turnover & 827 & 934 & 1152 & 2021 & 2732 \\
\hline Balance & -672 & -783 & -944 & -1837 & -2545 \\
\hline
\end{tabular}

Source: Ministry of Economy of the Slovak Republic

\section{What's next for Slovakia in Asia?}

The aim of this paper is to present an authentic view on the available, yet in many cases provoking, solutions to (albeit belated) entry of Slovakia into the ever-growing stream of goods exchange between Europe and Asia, while drawing inspiration not only from theoretical and practical knowledge, but also from the author's 5-year personal experience in promoting Slovak economic interests in the region. In revising it is necessary to recall that the awareness about Slovakia in the eyes of Asian public is extremely limited. Where still possible, it is strongly suggested to build on (the remaining) positive ties from the period of Czechoslovakia (the phenomenon is salient particularly in former partners within the now ceased Council for Mutual Economic Assistance). According to the newest issue of Brand Finance Nations Brands 2015, the value of brand "Slovakia" decreased by 9\% compared to last year.

On the continent, whose economic growth is based largely upon (cheap) production, it is impossible to compete by producing regular commodities - the goods must be remarkable for their high quality, distinctiveness and story. The position of Slovak entrepreneurs in Asia will benefit from efficient Slovak promotion adapted to local conditions (the view of Orava's pastures will, undoubtedly, warm every Slovak's heart, yet it will not encourage Asian tourists to visit our country - Slovakia must be promoted as a modern and, in some respects, a unique place). The complementarily of tourism promotion to trade is obvious. A Chinese customer owning an Audi Q8 is proud of the car's German origin despite the fact that it was manufactured in Devínska NováVes. The absence of a single unique product, which the majority of Asian public would associate with Slovakia, constitutes perhaps the greatest obstacle to our wider visibility in the region. It is necessary to utilise all the available instruments to change this status quo: perhaps to build a campaign based on - in Asia phenomenally popular - folk ensemble Lúčnica, or the Slovak orchestral music; from the perspective of innovations the leadership in IT security - ESET, developers of Sygic for Android and, perhaps, in a first place, on the unique project of flying car (Aero Mobil, by Štefan Klein, the constructor). The opportunity for success also lies in the area of Slovak modern glass art, crafts, fashion, design, and architecture. The visibility of Slovakia in Asia would grow proportionally through increasing the involvement of Slovakia (political, sports, etc.) on the continent even in ostensibly unrelated areas. In this regard, however, it is necessary to respect the Asian mentality, history, and specifics and adapt our modern, efficacious presentation accordingly. The share of large companies on export to the non-EU countries in 2013 constituted more than four-fifths $(81.9 \%)$ of the whole $(V y ́ v o z, 2014)^{3}$. Considering autonomous trade policies of foreign investors in Slovakia/transnational companies operating in Slovakia, support of proexport activities must focus largely on small and medium enterprises.

The small and medium enterprises (SMEs) sector is symptomatic by limited export experiences, especially outside of Europe. Exporting to more distant territories naturally incurs additional expenses,

\footnotetext{
${ }^{2}$ Commentary "Vývoj zahraničného obchodu SR za rok 2014 a predbežný odhad údajov za január 2015“,http://www.economy.gov.sk/ext_dokZo-dec_2014/145060c? ext=orig (accessed on 17 October 2015)

${ }^{3}$ Part „4.2.2 Vývoz MSP do krajín mimo EÚ, Postavenie MSP v zahraničnom obchode SR v roku 2013“, Slovak BusinessAgency
} 
linked to the transport, transport insurance, trade-loans risks preventions, know-how of local markets, overcoming the tariff barriers, etc.

\section{Conclusions}

Taking into consideration all the facts above and ideas, in author's view, to adapt to the current global trends, it is advisable that Slovakia considers implementing the following measures:

- Organisation of educational workshops for SMEs with the aim of getting to know the trade and socio-cultural specifics of Asian countries. Identification of instruments for supporting SMEs marketing efforts when expanding to non-European, less traditional markets. Provision of incentives- direct and indirect - to create new jobs linked to export to countries outside the continent. Facilitation and cooperation in building first-hand contacts (B2B).

- Geographical dis-balance between Slovakia and its Asian partners can in some instances be improved by joint efforts to promote national interests within the Visegrad 4 group (V4) or the EU. Slovakia should also consider a more proactive participation within regional integration initiatives, such as, in the economic sphere, the Asia Infrastructure Investment Bank - AIIB, or Asia Development Bank - ADB - initially at least as observers; and in initiatives, such as One Road, One Belt, and platforms China + CEE16, V4+Japan, V4+Korea, ASEAN, ASEM, etc.

- With regard to key countries of the region (India, Japan, South Korea, Indonesia, Vietnam), further measures could include drafting similar analyses as the June 2015 "Report on the status and possibilities of economic cooperation with China" and submitting it to the Government's Council for Export and Investments. Focusing on sectorial parallels between Slovak export and requirements of Asian markets (for example in the case of China - negotiations with CEFC - energetic, etc.). Elaborate on prospective areas, in which improvement of cooperation between Slovakia and Asia in sectorial politics is feasible (without further analyses, but with concrete steps) - a large sectorial project beyond the transnational corporations.

- Strengthen the Exim-bank ${ }^{4}$ toolbox when expanding into less traditional markets. Development of standard bank instruments in new territories.

- Adapting the network of Slovak embassies to specific requirements of Slovak entrepreneurs (for example in China, India, Vietnam - strengthening our presence in the regions - through our embassies and their branches, Consulates-General, offices of the Slovak Agency for Development of Investments and Business-SARIO, etc.; innovation centres in Japan, South Korea, etc.).

- Make greater use of the Slovak diaspora - particularly so-called "brain drain" for asserting economic and business interests of Slovakia in areas of R\&D and innovation. Utilise the Asian potential in the spheres of $R \& D$, innovations, start-up promotion (cooperation between universities, research centres, applied research, etc.).

- In the on-going free-trade agreements negotiations with Asian partners (including inter-linkages with other regional frameworks - for example the newly drafted TPP has the ambition to cover $40 \%$ of the global economy) take into account the strategic interests of Slovakia - after their conclusions the agreements will define the limits of mutual trade and export performance of Slovakia for decades to come. Emphasis not only on the traditional sectors.

- New possibilities arising in green technologies, biological agriculture and climate agenda in general.

- Undoubtedly complementary is the development of partnerships that aim to decrease transportation costs (seaports, shipping companies, etc.) including securing transport routes.

Table 4: Comparison: Diplomatic representations of similar European countries in Asia and the Pacific

\begin{tabular}{|l|l|l|l|l|l|l|l|l|l|l|l|l|}
\hline & AT & BE & CH & CZ & DK & FI & HU & HR & NO & NL & SE & SK \\
\hline Embassies in Asia & 12 & 13 & 17 & 17 & 16 & 13 & 11 & 5 & 16 & 11 & 15 & 9 \\
\hline
\end{tabular}

Source: MFAs webpages of countries concerned

${ }^{4}$ Export - Import Bank, a state-run institution to promote foreign trade e.g. by providing export credits and insurance 
For the sustainable prosperity of Slovakia, it is becoming more and more imperative to reshape the existing predominant orientation on the automotive industry and the EU markets (reaching apparently its peak), diversifying country's pro-export capacity (sectorally as well as geographically). Obviously, Asia's say on the global economy will continue to grow. At the same time, shifting our focus on this region fully corresponds with the strategy - or to be more precise the necessity - to profile the country in smart technologies. Exploration of new territories is undoubtedly associated with various risks of different nature. The author, however, believes - and the experiences of similar countries have had this assumption proven - that opportunities abound are worth overcoming the initial shyness. A few success stories would then likely wide-open the door for a more adequate, robust Slovak trade with the Asian continent.

\section{REFERENCES}

- Brand Finance Nation Brands 2015 http://brandfinance.com/knowledge-centre/reports/brandfinance-nation-brands-2015/, p. 15

- Commentary „Vývoj zahraničného obchodu SR za rok 2014 a predbežný odhad údajov za január 2015",http://www.economy.gov.sk/ext dok-zo-dec 2014/145060c?ext=orig (accessed on 17 October 2015)

- EU - Asia Security Factsheet, EEAS, eeas.europa.eu/asia/docs/eu in asia factsheet en.pdf

- Friedman, G. (2011). The Next Decade: Where We've Been ... and Where We're Going. Doubleday, 2011ISBN-13: 978-0385532945

- IMF Data Mapper, www.imf.org/external/datamapper/index.php

- Morvay, K. et al. (2015). HospodárskyvývojSlovenska v roku 2014 a výhlad do roku 2016. Bratislava: Ekonomický ústav Slovenskej akadémie vied, 2015 ISBN: 978-80-7144-242-4

- Paper "Stav a možnosti hospodárskej spolupráce Slovenskej republiky a Čínskej l'udovej republiky". Approved by the managing board of the MFEA, June 2015.

- Part "4.2.2 Vývoz MSP do krajín mimo EÚ, Postavenie MSP v zahraničnom obchode SR v roku 2013", Slovak BusinessAgency

- Pauhofová, I. -Svocáková, S. (2014). Analýza zahraničných investícií Číny (Rozhodovacieprocesypočaskrízy). Bratislava: Ekonomický ústav Slovenskej akadémie vied, 2014ISSN 1337-5598

- StratégiavonkajšíchekonomickýchvztáahovSlovenskejrepublikynaobdobie 2014 - 2020, Radavlády SR pre podporu export a investícií

- Svocáková, S.(2014). Aktivity Číny v Európe v období súčasnej krízy, Paradigmy budúcich zmien v 21. storočí. In: Globálnysvet - spoluprácaalebokonfrontácia? Zborníkstatí, 2014ISBN 978-80-7144212-7

- The World Bank Annual Report 2015, World Bank Group, 2015.

- Vývoj (2015): Vývojzahraničnéhoobchodu SR zarok 2014 a predbežnýodhadúdajovzajanuár 2015.http://www.economy.gov.sk/ext_dok-zo-dec_2014/145060c?ext=orig(accessed on 17 October 2015)

- World Development Indicators 2015, World Bank Group, 2015.

- World Economic Outlook 2015: Uneven Growth: Short- and Long-Term Factors, International Monetary Fund, 2015.

- WTO International Trade Statistics 2012, World Trade Organisation, 2012.

- WTO, Trade Profiles 2014: Trade Flows and Trade Policy Measures, World Trade Organisation, 2014. 